\title{
A Study on Application of Formative Evaluation in College English Listening Teaching
}

\author{
Hongyan Cai
}

\author{
College of Humanities, Shandong Agriculture and Engineering University, Jinan, Shandong 250100, China \\ Email: caihongyan@sdaeu.edu.cn
}

\begin{abstract}
Teaching evaluation has played an important role in college English teaching. An exhaustive, objective scientific, and precise evaluation system is the basic condition for achieving the teaching goals. This thesis aims at the empirical research on the application of evaluation in college English listening teaching in order to explore a formative evaluation system that complies with the traits of college English listening curriculum.

Keywords: formative evaluation, English listening teaching
\end{abstract}

\section{INTRODUCTION}

In the last few years, with the continuous progress of college English teaching reform, the importance of formative evaluation in classroom teaching has been recognized and cared more and more by English teachers and researchers in colleges or universities. The studies on the application of formative evaluation in college English is showing an increasing trend. According to the research methods and research contents, they can be divided into two categories: first, the theoretical research on the principles and methods of formative evaluation; The second is the specific research on application of formative evaluation in college English teaching, such as applying formative evaluation to oral English and English writing teaching; analysing the impacts of formative evaluation on students' reading comprehension through teaching experiments. Many of the previous studies have provided a lot of experiences and methods for college English teaching in China, but the research on the implementation of formative evaluation in English listening teaching of college is relatively rare. Based on previous studies, this thesis uses teaching experiments to study the feasibility of applying formative evaluation to college English listening teaching and find its impacts on teachers' teaching and students' learning.

\section{PROBLEMS OF THE EVALUATION IN COLLEGE ENGLISH LISTENING TEACHING}

The function of college English teaching is to help students master comprehensive language skills and related knowledge in listening, speaking, translation, reading and writing. Among them, the college English listening course plays a main role in developing students' listening and speaking skills. How to realize the teaching goals of the course deserves teachers' thinking. The way to train English talents is the transmission of knowledge and skills, while the way to verify talents is evaluation and practice. Teaching evaluation will directly affect the teaching process, and it will also affect whether learners can learn independently and participate in teaching activities positively. So, it is extremely necessary to apply the formative evaluation system as a diversified assessment method to college English listening teaching.

Unfortunately, such ideal teaching evaluation has not been fully reflected in college English listening learning and teaching. Specifically, the traditional evaluation of college English listening teaching only focuses on reflecting the learning results of students, ignoring the development of students' skills of listening and speaking during the learning process. The process of evaluation only focuses on the evaluation of teachers, and ignores students' self-evaluation and the student-to-student evaluation, neglecting the function of providing services for the growth and development of students, neglecting the cultivation of comprehensive quality such as students' emotions, learning attitudes, cross-cultural awareness. Affected by this traditional teaching evaluation model, some problems have emerged in college English listening teaching: students have no confidence to finish listening and speaking tasks, they are passively participating in listening and speaking activities in class. In the college English listening class, there is a mechanical model of "teachers playing video and audio materials [7], students listening and watching them, then teachers checking the answers [6]." Students are lack of the enthusiasm for self-training in listening and speaking after class. The result is that students' speaking and listening ability cannot be effectively improved. In a word, the traditional evaluation mode has made students lose the driving force of college English listening learning, and it is hard to stimulate students' enthusiasm, initiative and creativity, which severely hinders the development of students' English listening and speaking ability. In addition, the traditional evaluation model also ignores the individual differences of students and the creativity of teachers' teaching. 


\section{THEORETICAL BASIS}

\subsection{Howard Gardener's Multiple Intelligence Theory}

In 1983, Howard Gardener, a well-known developmental psychologist at Harvard University in the United States, put forward the theory of intellectual structure. He believes that the basic nature of intelligence is plural. In Gardner's opinion, establishing a scientific evaluation system is an important way to reflect the value of multiple intelligence theory. He sees evaluation as the process of observing the development of an individual's own skills and potential. And he thinks that the evaluation should be the judgment based on an individual's ability of solving problems and his ability of operating. Gardner believes that evaluation should be a natural part of the teaching process, and it should be integrated into the teaching process to reflect the development level and development trajectory of students timely and truly. In addition, Gardner's evaluation theory advocates multiple evaluations, including: multiple evaluation subjects, multiple evaluation methods, and multiple evaluation contents. Gardner's evaluation theory also advocates that evaluation should be centred on individual student [3], that is, the evaluation plan should take individual difference into account, attach importance to the individual development, and fully excavate the individual potential [4]. This evaluation can promote students to participate in all aspects of teaching process, stimulate students' initiative in learning, and improve their autonomous learning ability.

\subsection{Bloom's Formative Evaluation Theory}

Bloom's formative evaluation is carried out during or after a phased teaching process. It uses one or more feedback methods to discover the achievement of students' learning goals [2]. Students who do not reach the learning goals can be re-evaluated and be provided necessary guidance and help from teachers, so that they can achieve their learning goals. Therefore, Bloom's formative evaluation theory has important practical significance for improving students' quality.

Formative evaluation has various forms, such as classroom learning activity evaluation, after-class homework assessment, status of participation in extracurricular activities, self-evaluation of learning effects, study files, questionnaires, interviews, parents' feedback, and usual quiz. Formative evaluation can adopt a variety of evaluation and recording methods such as rating, descriptive evaluation, portfolio evaluation or scoring.

Teachers need to respect the following principles when using formative evaluation in their teaching:

\subsubsection{Developmental Principles}

The purpose of evaluation in the teaching is to promote students' development. We know one of the essential goals of the teaching is to stimulate students' learning enthusiasm in order to facilitate their continuous development and learning. When teachers evaluate, they must take care of students' learning characteristics and make evaluation become the motivation and source to encourage students to learn.

\subsubsection{The comprehensive principle}

The evaluation should closely follow the teaching objectives of the curriculum and fully reflect the status of students' achievement. The key goal of English listening learning teaching is to make students understand and communicate. So, the evaluation of students should focus on listening and speaking abilities, and should not be limited to cultivate only one of them.

\subsubsection{Procedural principle}

As a tool to promote the development of students' learning, evaluation must run through the entire process of student learning activities. Only continuous evaluation can measure the gap between students' learning and teaching goals at any time. Teachers should find the shortcomings of students in time and offer them necessary guidance for learning.

\subsubsection{Clarity principle}

In the process of teaching, the requirements and purposes of evaluation must be clear. Teachers should make students know what they want to achieve. with a clear understanding, students are encouraged to participate in evaluation activities positively, and often take the initiative to compare their learning with expected goals. So, evaluation becomes the students' own businesses, which can not only stimulate students' learning interests, but also cultivate their initiative and sense of responsibility.

\section{APPLICATION OF FORMATIVE EVALUATION IN ENGLISH LISTENING TEACHING}

\subsection{Research Purpose}

This research aims to understand the following two aspects through questionnaire surveys and teaching experiments.

(1) What problems are there in college English listening teaching under the current evaluation mode?

(2) How does the application of formative evaluation affect students' English listening learning? 


\subsection{Subjects}

69 students from 2 classes of the College of Humanities were selected to participate in this questionnaire survey and empirical study. One class is regarded as the experimental group and the other one is regarded as the control group. There is no difference between the experimental class and the control class in the aspects of teaching purpose, teaching tasks, teaching periods and teaching materials. The difference is that the former class focuses on the formative evaluation coordinated with the original evaluation model, while the latter class still uses the traditional final evaluation method.

\subsection{Research Process}

The time of teaching experiment is the latter semester of 2019.

The researcher designs and implements a questionnaire survey in the early stage of the experiment to find the issues related to English listening teaching under the current evaluation mode. The questionnaire was designed by the teachers based on repeated discussion. It includes 15 multiple choice questions and 1 open-ended question, which can help to find the present status of students' English listening learning. It specifically involves the following aspects: students' cognition, motivation and attitude towards English listening learning; difficulties during the process of English listening learning; evaluation of its teaching methods and teaching effects [8]; recognition of teachers' teaching strategies; views on evaluation models of its teaching; Comments and suggestions on application of formative evaluation. The survey results show that students lack interests in English listening learning. $65 \%$ of students feel that it is difficult for them to improve their English listening skills; $29 \%$ of them have an indifferent attitude towards English listening learning; the vast majority (90\%) of students agree that "relying on listening classes to improve listening skills is not enough". Only 19\% of students can practice English listening independently after class every week. On the perspective of the listening teaching method, some students report that the current English listening teaching method is a bit monotonous, they have "no sense of achievement", they thought "I didn't feel how much my listening ability has improved", and some students even suggested that English listening lessons can be completed by students themselves.

Then, the researcher formulated and implemented a formative evaluation project for English listening teaching. With the reference of the results from the above questionnaire survey, combined with the relevant theories of formative evaluation, the research initially formulated a formative evaluation project for English listening teaching (accounting for $30 \%$ of the final score), which specifically includes four parts such as study files, online learning, performance in class and test on listening ability.

Study file (5\%): At the beginning of the semester, students are required to work out their own learning goals and plans for the whole semester. They are asked to schedule their English listening learning each day and record the specific implementation process. They must self-evaluate the completion of their study plans. Teachers will check the learning files of students frequently in order to make feedback on the progress of students' English listening learning.

Online learning (10\%): First, Students should complete the designated listening practices on the designated websites or in the recommended books from the teachers. Second, students must complete the tasks such as learning and testing on English listening through learning online courses timely according to the teacher's arrangement.

Performance in class (10\%): Teachers observe the students' performance in class, observe their self-consciousness and enthusiasm when discussing and answering questions, then give a comprehensive evaluation based on their performance. The evaluation method has changed from the previous single teachers' evaluation into a combination of teachers' evaluation, students' self-evaluation [1] and student-to-student evaluation. As evaluation subjects, Students can participate in evaluation activities.

Test on listening ability (5\%): A quiz on English listening is conducted every two weeks. The test questions designed by teachers are based on the designated websites or reference books. Teachers mainly check the completion of students' online learning and the improvement of English listening ability. The main forms of the test are true or false questions, compound dictation, and answering questions.

At the end of the experiment, researcher carried out interviews and questionnaires survey from both the teachers' and students' sides in order to find the impacts of the implementation of formative evaluation in students' English listening learning and in teachers' English listening teaching.

Through the questionnaire survey towards students, we can find that $86 \%$ of the students are positive about the application of formative evaluation in English listening teaching, and $75 \%$ of the students believe that the establishment of study files will be helpful to "make them manage their English listening learning better". $76 \%$ of the students feel that they have more confidence to improve their English listening ability.

We know formative evaluation focuses on the learning process, not just the learning results. Through interviews with teachers, the researcher finds, implementing formative evaluation in English listening teaching process, the teachers can timely understand the progress and changes that students have made during the learning process, and they can take corresponding measures based on the individual's different performance to encourage their sustainable development [3]. Teaches can give those who have not made significant progress psychological help and guidance.

\section{CONCLUSION}

In a word, the application of formative evaluation in college English listening teaching has played an important role in 
[8] Weir, C. J. \& Roberts, J. Evaluation in Language Teaching [M]. Cambridge: Cambridge University Press, 2001. improving students' English listening ability and
autonomous learning ability. At the same time, it has played a good spur on teachers' reflection on their teaching [5]. In other words, the application of formative evaluation in English listening teaching can encourage students to ponder their learning behaviour and adjust their learning plans on time. Meanwhile, it can also encourage teachers to ponder their teaching behaviour and adjust their teaching projects on time. In this way, teachers' teaching and students' learning can enter new teaching sessions in a better state, and a virtuous circle of teaching and learning can be realized. However, due to the numerous projects of formative evaluation, all those projects will greatly increase the burden on teachers. Besides, most of the teachers have insufficient experiences and skills on modern online teaching methods in the process of application of formative evaluation in English listening teaching. Nowadays, the online and offline mixed teaching mode is popular. Teachers have offered students online learning related to English listening learning in the process of application of formative evaluation. However, most teachers lack the skills and experiences of online teaching related to English listening teaching, so colleges and universities should offer such training to ensure that teachers can smoothly use modern education methods to conduct their teaching. At the same time, as for students, compared with traditional evaluation methods, they must generally adapt the formative evaluation implemented in English listening teaching. Some students think that this evaluation method is a waste of time. In response to this situation, teachers should communicate more with students so that students understand the practical significance of application of formative evaluation in college English listening teaching.

\section{ACKNOWLEDGMENT}

This work was supported by Teaching Reform

Research Project of Shandong Agriculture and Engineering University(17XJY25).

\section{REFERENCES}

[1] Black, P. \& William, D. Assessment in classroom learning [J]. Assessment in Education, 1998, (5).

[2] Bloom, B. S. Evaluation to Improve Learning [M]. New York: McGraw-Hill, 1981.

[3] Cowie, B. \& Bell B. A Model of Formative

Assessment in Science Education [J]. Assessment in

Education, 1996, (2).

[4] Gardner, H. Multiple Intelligences. Basic Books

USA, 1993.

[5] Genesee, F. \& Upsjur J. A. Classroom-based

Evaluation in Second Language Education [M].

Beijing: Foreign Language Teaching and Research

Press, 2001.

[6] Harmer, J. How to Teach English [M]. Beijing:

Foreign Language Teaching and Research Press, 2000.

[7] Lonergan, J. Video in Language Teaching [M].

New York: Cambridge, 2000. 